\title{
Physical and chemical studies in the region of the southern slope of Mount Elbrus, Caucasus
}

\author{
A. M. Bazhev ${ }^{1, \dagger}$ O. Rototaeva, ${ }^{1}$ J. Heintzenberg,${ }^{2}$ M. Stenberg ${ }^{3}$ J. F. Pinglot ${ }^{4}$ \\ ${ }^{1}$ Institute of Geography, Russian Academy of Sciences, Staromonetny 29, Moscow, Russia \\ ${ }^{2}$ Institute for Tropospheric Research, Permoserstr. 15, D-04303 Leipzig, Germany \\ ${ }^{3}$ Department of Physical Geography, Stockholm University, S-10691 Stockholm, Sweden \\ ${ }^{4}$ Laboratoire de Glaciologie et Géophysique de l'Environnement du CNRS, 38402 Saint-Martin d'Hères Cedex, France
}

\begin{abstract}
For glaciological and meteorological reasons Mount Elbrus, Caucasus, was chosen as a site for physical and chemical pilot studies of ice cores. This study was the first step towards systematic studies of impurities in glacier ice on Mount Elbrus. In 1990 two ice cores, each $17 \mathrm{~m}$ deep and spaced $10 \mathrm{~m}$ apart, were taken at an elevation of $4100 \mathrm{~m}$ on the Bolshoy Azau glacier on the western slopes of Mount Elbrus. The cores were used for different physical and chemical analyses. Structure, texture and ice microstructure were studied. Chemical analyses of major ions $\left(\mathrm{SO}_{4}^{2-}, \mathrm{NO}^{3}, \mathrm{~K}^{+}\right.$and $\left.\mathrm{Na}^{+}\right)$and measurements of insoluble light-absorbing material and radioactivity $\left({ }^{137} \mathrm{Cs}\right.$ and total $\beta$ activity) were made. With the results of the physical and chemical analyses of these two ice cores, the possibilities of utilising the ice for the study of trace substances deposited after long-range transport from Europe were explored. Ice-stratigraphic methods made it possible to establish the annual accumulation rate. A reference horizon was established from the depth variation of ${ }^{137} \mathrm{Cs}$ and total $\beta$ activities that showed a well-defined peak of their activities coinciding in time with the 1986 Chernobyl accident. The results of this study show that Mount Elbrus is a useful archive for atmospheric composition downwind of Europe.
\end{abstract}

\section{INTRODUCTION}

The Elbrus massif lies in the centre of the Caucasus mountain range. It is distinguished by scale and complexity, reflecting a wide range of conditions and processes which occur on the glaciers of the surrounding area. With its highest peak at $5642 \mathrm{~m}$ a.s.l., Mount Elbrus rises high above the surrounding mountain tops, reaching the free troposphere. Its slopes are exposed to air masses from all directions. The Elbrus glaciers accumulate atmospheric precipitation and with it trace substances, including those of human origin advected over long distances. Winds from the European source region often take a southern route over the Black Sea to the western Caucasus mountains (Benkovitz and others, 1994; personal communication from S. Schwartz http://tassle. das.bnl.gov/sulfate_model.html). These facts make it interesting to investigate the thick ice layers of Mount Elbrus. A comprehensive analysis of the cores taken from the glaciers on Mount Elbrus would not only make it possible to increase our understanding of the evolution of glaciation and climate in the Caucasus, it would also enable researchers to study the year-by-year changes of upwind characteristics of anthropogenic environmental pollution over recent decades. The purpose of the Elbrus project was to obtain

the annual variation of all components of the mass balance,

the characteristics of the solid precipitation regime, the chemical composition of the glaciers, and

the influence of the glaciers on the composition of river waters.

As a first step towards systematic studies of impurities in glacier ice on Mount Elbrus, two short cores were taken on the Bolshoy Azau glacier in 1990. Below, we report on the results of physical and chemical analyses of their composition. The results are discussed in comparison to the composition of snow and ice at other remote sites and in relation to a specific deposition event.

\section{GLACIOLOGICAL AND METEOROLOGICAL CONDITIONS ON MOUNT ELBRUS}

To understand the ice distribution of Mount Elbrus, we need to know the controlling processes. Altitude is the main factor affecting the shape and composition of the Elbrus glaciers. The vertical extent of contiguous glacier slopes exceeds $2 \mathrm{~km}$. Different elevations result in different temperature conditions, different conditions of precipitation and different wind regimes, as well as a different slope morphology. Horizontal differences are also significant, and have two main causes. First, there are persistent strong westerly winds, causing snow transfer and resuspension across the slopes throughout the year. Secondly, Elbrus glaciation is confined to the volcanic top of the mountain. The complex subglacial relief of the lava massif is reflected in the glacier surface as changes of slope, slope bends, ledges and nunataks.

\footnotetext{
$\dagger$ Deceased.
} 
The present studies are devoted to the Bolshoy Azau, Maliy Azau and Garabashi glaciers, on the southern slope of Elbrus. The complex of glaciological observations encompassed elevations from $3100 \mathrm{~m}$ at the terminus of the Maliy Azau glacier to $5300 \mathrm{~m}$ at the Elbrus saddle (cf. Fig. 1). Glacier formation and changes with time were studied by means of borehole and pit sampling. Each year, these measurements took place on different points of the glaciers according to a general profile presented in Figure 1. The Garabashi glacier was the most intensely studied because it is included in the World Glacier Monitoring Programme.

We conducted observations for over 10 years, from the 1983-84 to the 1993-94 balance year. This period was characterised by variable conditions of snow accumulation and melting and included extreme years (e.g. 1985-86, 1993-94).

The number of days with precipitation on the glaciers of the region is high, including $70 \%$ of days during the winter (Kotlyakov and Plam, 1964). With increasing altitude the amount of precipitation increases, at least up to $4000 \mathrm{~m}$ altitude. According to data from precipitation gauges, in the valley, at $2150 \mathrm{~m}$ (Terskol Settlement) precipitation amounts to $790 \mathrm{~mm}$; at $3050 \mathrm{~m}$ elevation to $810 \mathrm{~mm}$; and near Priyut of Eleven $(4050 \mathrm{~m})$ to $1130 \mathrm{~mm}$. The readings of precipitation gauges may be severely affected by strong winds at high elevations.

During the cool season, precipitation events are invar- iably accompanied by strong winds and blizzards. On Priyut of Eleven, westerly and northwesterly winds predominate in winter, their frequency of occurrence being $86 \%$. Sometimes the wind velocity reaches $55 \mathrm{~m} \mathrm{~s}^{-1}$ (Matyukhin, 1960). Westerly winds are characteristic of the influence of the free troposphere.

Summer precipitation in the accumulation area of Elbrus glaciers falls in solid form. Near the weather station at $3830 \mathrm{~m}$ elevation, $30-40 \mathrm{~g} \mathrm{~cm}^{-2}$ of snow falls during summer.

The average January temperature in the accumulation area of the glaciers at elevations of $3800-4500 \mathrm{~m}$ is $-17^{\circ}$ to $-22^{\circ} \mathrm{C}$, reaching $-28^{\circ} \mathrm{C}$ at the top of Elbrus. The zero isotherm in August, the warmest month, only reaches $3850 \mathrm{~m}$, on average, while near the summit the temperature recorded during this season has never exceeded $-14^{\circ}$ to $-15^{\circ} \mathrm{C}$ (Borovik and Kravtsova, 1970). By and large, the distribution of snow on the slopes of Mount Elbrus is determined by height differences and snow transport by westerly winds.

In general, the distribution of snow accumulation with elevation has been virtually constant throughout the years of observations, the differences being mostly in the absolute values. This is confirmed by the stable shape of the accumulation curves plotted for the main altitudinal profile of the Garabashi glacier (cf. Fig. 2). Within the belt of maximum snow accumulation at elevations of $3600-4000 \mathrm{~m}$, the average value of annual snow accumulation on this profile

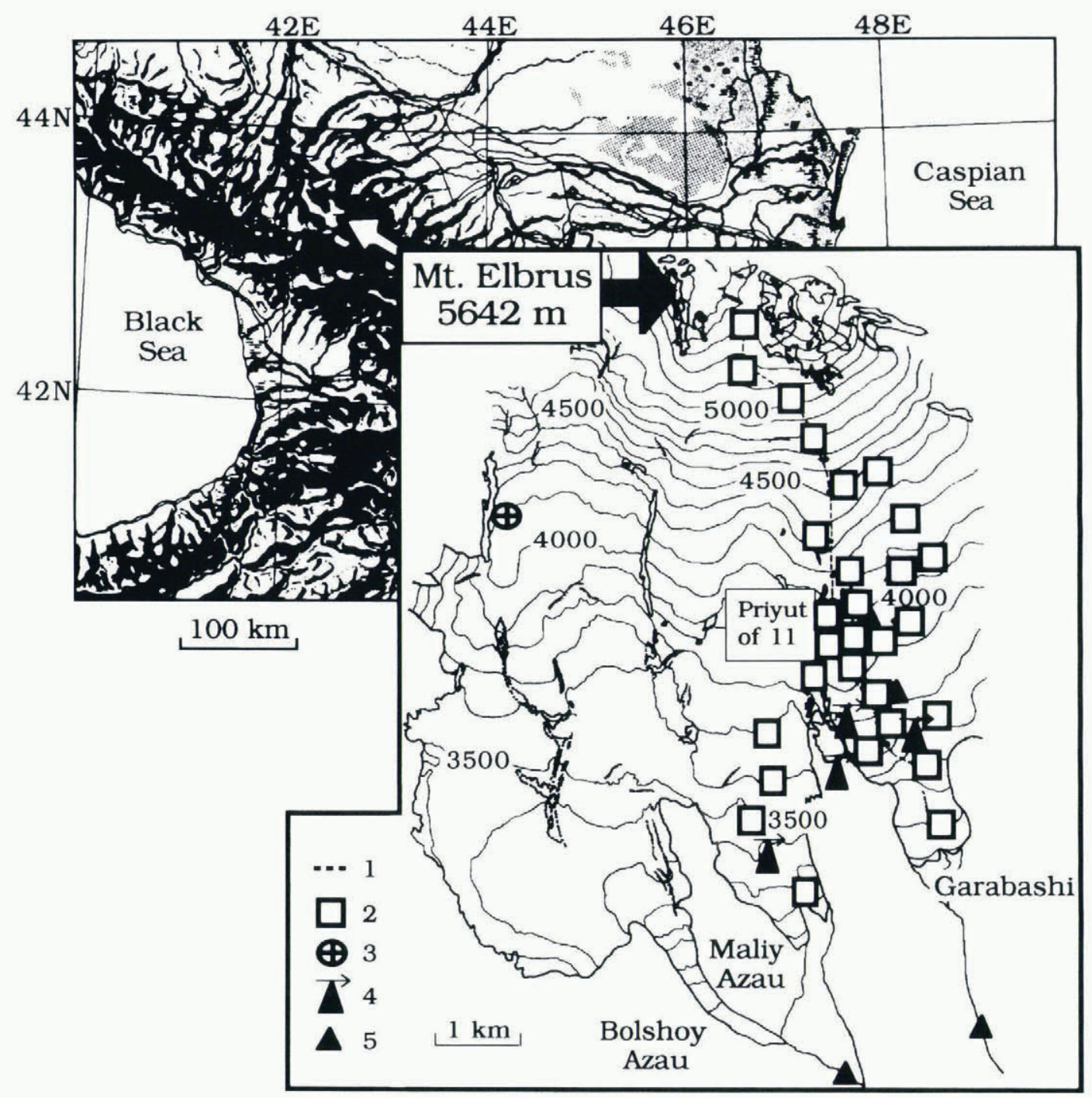

Fig. 1. Area of observations on Mount Elbrus, Caucasus: 1, main altitudinal profile; 2, permanent points for study of ice mass in boreholes and pits; 3, boreholes for cores one and two; 4, meteorological stations; 5, sampling points for heavy metals. 


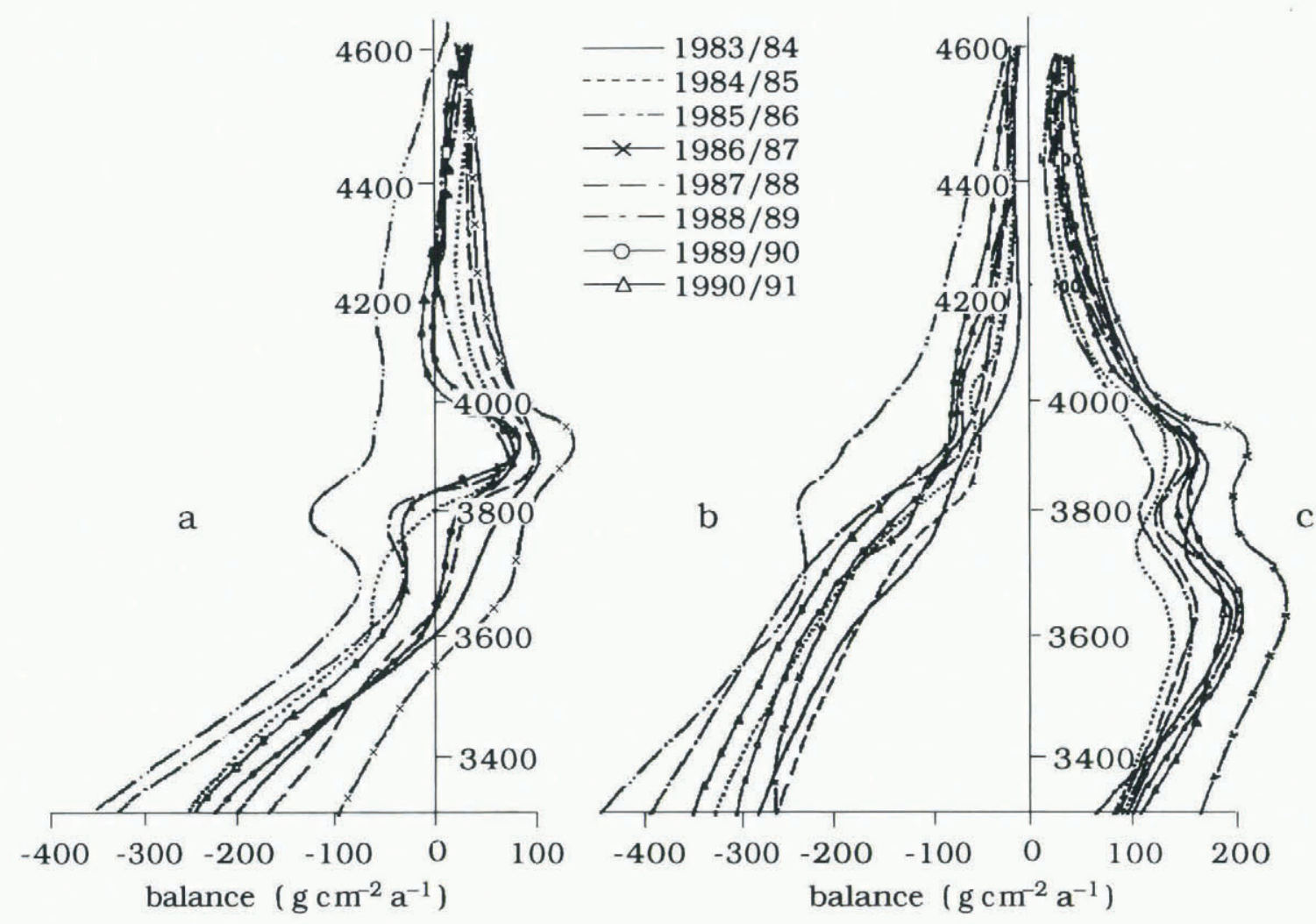

Fig. 2. Altitude dependence of the mass balance (a) along the altitudinal profile, and of its components, annual ablation (runoff) (b) and accumulation (c) in different years.

equals $160-180 \mathrm{~g} \mathrm{~cm}^{-2}$. In the central part of the glacier it is $200-250 \mathrm{~g} \mathrm{~cm}^{-2}$. At elevations above $4000 \mathrm{~m}$, on the steep slope, the value of accumulation across the profile drops to $50-20 \mathrm{~g} \mathrm{~cm}^{2}$.

The distribution of snowmelt on the Elbrus slope is, above all, dependent on the elevation. The shortening of the summer season as the altitude increases, the decreasing sum total of positive temperatures and increasing albedo cause a gradual decrease of the annual snowmelt with increasing altitude. The range of melt values is fairly large: from 350$400 \mathrm{~g} \mathrm{~cm}^{-2}$ at the tongues of glaciers to $15-20 \mathrm{~g} \mathrm{~cm}^{-2}$ at 4600 m elevation.

The average melting period of glaciers is from the end of May to mid-September. The most intensive melting of the glacier surface occurs during the second half of July and the first half of August, when up to $4-5 \mathrm{~g} \mathrm{~cm}^{-2}$ of water melts during a single day at $3830 \mathrm{~m}$ elevation.

Ablation on the Elbrus glaciers may be said to equal the runoff because here, as with other glaciers of the Caucasus, according to observations by different authors, annual values of evaporation are low and virtually equal to those of condensation.

The conditions of runoff at the glacier tongues and in the areas of nourishment differ greatly. In the ablation area, where runoff and melting are equal, runoff is mostly determined by the value of ice melting, its intensity being $2-3$ times higher than the value of snowmelt. Above the firn line, ablation drops abruptly, all the curves of runoff exhibiting a sharp bend (cf. Fig. 2). This is caused mainly by the fact that some of the meltwater is used in feeding internal infiltration. Maximum runoff losses are in the section where the firn mass is thickest and absorbs meltwater, i.e. at elevations of $3900-4000 \mathrm{~m}$. Near the lower boundary of this zone, half of the meltwater goes to runoff, and near its upper boundary only a quarter. At higher elevations, where the firn layer cools not only in winter, but also in summer during frequent spells of freezing temperatures, the layer absorbs all meltwater. The average elevation of the zero isoline of annual runoff is $4000-4200 \mathrm{~m}$, occasionally even lower.

\section{THE SAMPLING SITE}

An analysis of the glaciological conditions on Elbrus enabled us to choose the most informative sites for the study of the ice layer. To study the deposition of atmospheric pollutants from distant sources, a drilling site at higher elevations was more appropriate. For this purpose, we selected a relatively gentle slope on the western part of Bolshoy Azau glacier, at $4100 \mathrm{~m}$ elevation. According to exploratory radio-sounding data, the ice thickness in the drilling region is $60-70 \mathrm{~m}$. The ice flow of $1-2 \mathrm{~m} \mathrm{a}^{-1}$ is rather slow. The drilling point was in a cold infiltration-recrystallisation zone featuring minor melting and relatively low snow accumulation. This guaranteed a maximum number of annual layers per unit of core length, with a low risk of missing annual layers, and ensured the drilling of not too deep a borehole through the entire firn mass.

\section{THE ICE CORES}

On 11-13 September 1990, two boreholes spaced $10 \mathrm{~m}$ apart were each drilled to a depth of $17 \mathrm{~m}$. The drilling was carried out during the daytime, with air temperatures at $-2^{\circ}$ to $-6^{\circ} \mathrm{C}$. A hand auger drill was used with $150 \mathrm{~cm}$ long metal snap bars. The $80 \mathrm{~cm}$ long auger drill was $110 \mathrm{~mm}$ in diameter. The length of the core sections after each drilling pass was $56-74 \mathrm{~cm}$ with a diameter of $90 \mathrm{~mm}$. A total of $34 \mathrm{~m}$ of core was taken. The yield was nearly $100 \%$. The sections were packed in clean polyethylene bags which were 
sealed at the sampling point and then placed in heat-insulated containers. After the drilling, the containers with the core were delivered by helicopter to the city of Nalchik, where they were stored in a freezer before being airlifted to the cold laboratory of the Department of Meteorology of Stockholm University (MISU). The core was kept in a frozen state all the time. The entire core from both boreholes was processed in the cold laboratory at MISU.

Core one (borehole one) was used for chemical analyses. Core two (borehole two) was used for glaciological analyses in the cold laboratory. The structure and texture of the entire core were described in detail with the aid of a light table. The density, volumes of open pores, and contents of bubbles and pockets were determined by hydrostatic weighing (Bazhev and Bazheva, 1962) in 109 samples taken over the entire length of the core down to $17 \mathrm{~m}$ depth.

\section{TRACE ANALYSES}

In order to compare concentration levels of major soluble and insoluble impurities in Elbrus firn with data from other remote areas, core one was processed in a cold laboratory $\left(-15^{\circ} \mathrm{C}\right)$ under clean-room conditions. Cutting and cleaning of the core was done on a clean-air bench, and particle-free suits, polyethylene gloves and face masks were worn for this task. The core was subdivided with $5 \mathrm{~cm}$ resolution and cleaned by cutting off about $1 \mathrm{~cm}$ of the outer core section and $0.5 \mathrm{~cm}$ at the ends, with a stainless-steel knife. The cleaned samples of the core were then put into plastic cups pre-washed with double-deionised water (resistance $>18 \mathrm{MOhm}$ ) from a Milli-Q system. The cups were stored in the freezer $\left(-28^{\circ} \mathrm{C}\right)$ until the time for the analyses. The samples were then melted in the cups and analyzed using an integrated ion chromatograph for major ions $\left(\mathrm{SO}_{4}{ }^{2}\right.$ and $\mathrm{NO}_{3}{ }^{-}$) and the major cations $\left(\mathrm{Na}^{+}\right.$and $\left.\mathrm{K}^{+}\right)$. The anions were analyzed on an AS11A column, and the cations on a CS3 column. The mean uncertainty of the analyses for all ions was about $\pm 5 \%$.

For the subsequent light-absorption analysis, about $10 \mathrm{ml}$ of each melted sample was sucked on a clean bench through a masked $37 \mathrm{~mm}$ diameter Nuclepore ${ }^{\mathrm{R}}$ membrane filter with $0.2 \mu \mathrm{m}$ pore size. In order to test the efficiency of these filters, artificial soot hydrosol standards with mass median diameters of about $0.2 \mu \mathrm{m}$ were sampled through filters with 0.1 and $0.2 \mu \mathrm{m}$ pore size. The smaller pore sizes yielded about twice the optical signal of the $0.2 \mu \mathrm{m}$ pore size. Bearing in mind that the insoluble particles deposited in Elbrus snow are mostly of crustal origin and thus larger than $1 \mu \mathrm{m}$ in diameter, we concluded from the hydrosol tests that the efficiency of our meltwater filtration must be at least $50 \%$. Fifty of the filters were then analyzed for light-absorbing particles with an optical technique (Heintzenberg, 1988). The analytical mean uncertainty was estimated to be $\pm 15 \%$.

The interpretation of the absorption results in terms of elemental carbon (EC) builds on the fact that EC in most atmospheric settings is the dominating particulate matter in the atmospheric aerosol. Mass concentrations of EC are derived by converting the absorption data with the specific absorption efficiency of $9.6 \mathrm{~m}^{2} \mathrm{~g}{ }^{1}$ of the artificial soot which is used for the calibration of the photometer Heintzenberg, 1982). In areas with high contributions of crustal material to the local aerosol (as on Mount Elbrus) the interpretation of the results in terms of $\mathrm{EC}$ concentrations is questionable.
Thus, we bear in mind that EC in the present context stands for the amount of insoluble light-absorbing material.

For the metal analyses, surface samples of wet snow or ice were placed with a plastic scoop into polyethylene bags which were emptied into polyethylene bottles after melting. All instruments and containers were cleaned with 2-3\% $\mathrm{HNO}_{3}$ solutions and 3-4 times with double-distilled water. At the Soil Institute Laboratory, Moscow, the dry part of the samples was sifted through a $10 \mu \mathrm{m}$ sieve before analysis with a TEFA-6110 X-ray fluorescence analyzer made by Ortek, U.S.A.

\section{RADIOACTIVITY MEASUREMENTS}

The parts left over from the cleaning of the core sections in the part of the core that was suspected to be in the time period around the 1986 Chernobyl accident were used for radioactivity measurements $\left({ }^{137} \mathrm{Cs}\right.$ and total $\beta$ activities). Ice from these sections was first melted and acidified $(\mathrm{HCl}$, $\mathrm{pH}=2.4$ ) and then filtered through ion-exchange filters (Macheray Nagel, MN 616 type, LSB and LSA) for 2 hours with a peristaltic pump with a flow of $51 \mathrm{~h}^{-1}$ (Delmas and Pourchet, 1977). After the filtration process, both anion and cation filters were mounted between two thin Mylar films in an adhesive filter holder for subsequent analysis. These samples (weight of the two ion-exchange filters $\approx 13$ $\mathrm{mg} \mathrm{cm}{ }^{-2}$ ) were then suitable for total $\beta$ counting at the Laboratoire de Glaciologie in Grenoble, France.

The low-level beta counter with an automatic sample changer for the radioactivity measurements has been described in Pinglot (1978) and Pinglot and Pourchet (1979). A surface barrier or an ion-implanted passivated silicon (PIPS) detector (sensitive area $200 \mathrm{~mm}^{2}$; depth layer of the detector $300 \mu \mathrm{m} ; 17 \mathrm{keV}$ alpha resolution) is connected in anti-coincidence with a large gas-flow guard counter, acting as a cosmic-ray detector.

Efficiency measurements were conducted with calibrated sources derived from liquid solutions obtained from the Laboratoire de Métrologie des Rayonnements Ionisants, Commissariat à l'Énergie Atomique, France, and the Amersham Company, U.K. A precise volume is dropped on the same ion-exchange resin paper used during the filtration of melted snow (Delmas and Pourchet, 1977). The efficiency for ${ }^{90} \mathrm{Sr}$ is about $18 \%$ (for a filter weight of $13 \mathrm{mg} \mathrm{cm}^{-2}$ ), and the background above $150 \mathrm{keV}$ is 10 counts $\mathrm{h}^{-1}$.

For the gamma spectrometry a low-level spectrometer (anti-Compton-suppressed) has been developed (Pinglot and Pourchet, 1994). The high-purity, N-type germanium detector, low-background-specified, has a $20.6 \%$ relative efficiency. This type of detector exhibits an excellent efficiency down to low energies as the $46.52 \mathrm{KeV}$ line of ${ }^{210} \mathrm{~Pb}$. The ${ }^{137} \mathrm{Cs}$ analysis has a $4 \mathrm{mBq}$ detection threshold for 2 days counting time and a $97.5 \%$ confidence level, and for our standard geometry (10 g samples) (Pinglot and Pourchet, 1995).

\section{PHYSICAL RESULTS}

The cores were characterised preliminarily at the drill-site. Through stratigraphic inspection, the boreholes revealed 11 complete layers; the boundaries are well characterised by summer horizons. These mark the end of the glacier balance year. The length of the balance year varies with time. On Mount Elbrus glaciers it ends on average in mid-September. 
Insoluble material concentrates in the melting snow during summer melting. During the same period the dry deposition of crustal material from bare mountain surfaces increases. Repeated melting and freezing during the warm season leads to the formation of a horizon with high ice content and typical ice seams and lenses. In subsequent years infiltrated water is blocked by, and freezes at, these horizons. Consequently, firn density increases at these horizons.

The summer horizons were visually determined quite reliably through the sum of the above characteristics. Their thickness is usually $4-15 \mathrm{~cm}$, sometimes more. The boundaries of the four most recent years are well pronounced in the white firn. The boundary of 1985-86 is marked by many dark coarse mineral particles which can be observed with the naked eye. Below that layer, "leakage" and ice lenses were observed. In deeper parts of the core, all summer horizons were distinguishable as layers with dense infiltration ice with visibly stratified texture and light brown colour.

The structure of the cores from both boreholes was almost identical. There is only a slight difference in the thickness of annual layers. The inter-annual changes in layer thickness are very similar (cf. Fig. 3). They coincide well with oscillations of mass balance in the same latitude zone $(4100 \mathrm{~m})$ measured every year on the Garabashi glacier. The years 1983-84 and especially 1986-87 were extremely snowy, whereas the years $1982-83$ and 1985-86 were remarkable for intensive snowmelt and less precipitation, which accounts for the high ice content in the respective annual layers (cf. Figs 2-4).

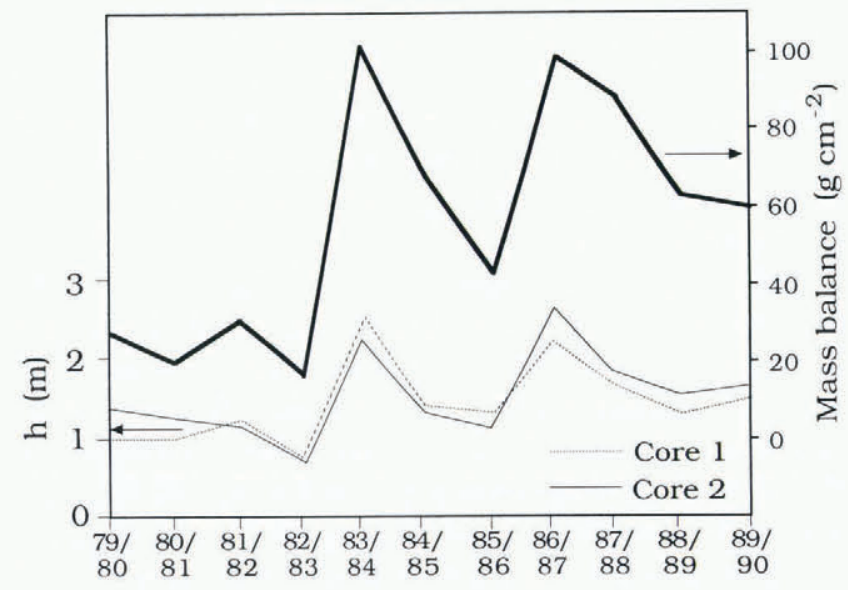

Fig. 3. Thickness of annual layers in different years in boreholes one and two. Bold line shows annual fluctuations in mass balance of the Garabashi glacier at $4100 \mathrm{~m}\left(\mathrm{~g} \mathrm{~cm}^{-2}\right)$.

The boundaries of the annual layers were confirmed to some extent by our laboratory analyses. They can be recognised in some of the local maxima in the results of the soot photometer and the radioactivity data (cf. Figs 4 and 5). From the depth variation of ${ }^{137} \mathrm{Cs}$ and of total $\beta$ activity a reference horizon was established from the well-defined peak of their activities in an annual layer, coinciding in time with the Chernobyl accident which was also noted in similar radioactivity data of precipitation samples in Hungary (Csongor and others, 1986) and in the Himalaya (Nijampurkar and Rao, 1990). The Chernobyl signature is given by the measured ratio $(\approx 2)$ at the time of deposition in 1986 of ${ }^{137} \mathrm{Cs}$ and ${ }^{134} \mathrm{Cs}$. Based on the mean value of the density of the corresponding samples, the ${ }^{137} \mathrm{Cs}$ fall-out from Chernobyl is $\approx 200 \mathrm{~Bq} \mathrm{~m}^{-2}$, corrected to 1986 .
As was already noted, the drilling site is in the cold infiltration-recrystallisation zone, where all snowmelt water refreezes in the firn mass, i.e. appears as internal infiltration feeding. Where there is no runoff the annual increment is equal to the accumulation value.

The water equivalent (water storage) of the upper annual layers will increase somewhat as these lie deeper in the firn mass, but at the expense of internal nourishment during subsequent years. Judging by the depth where the borehole temperature changed to negative values which we measured in the borehole during the drilling operation, and according to the calculations carried out in compliance with the procedure set out in Bazhev (1980), meltwater infiltrates only to a depth of 7-8 m, i.e. approximately down to the fifth annual layer. This conclusion is confirmed by the nature of change of the depth density, porosity and bubble content of ice (cf. Fig. 4). Down to $8 \mathrm{~m}$ depth, density increases rapidly, while porosity decreases because the open pores are filled increasingly with infiltration ice. A certain increase of the bubble content of ice (especially in the fifth annual layer) occurs due to part of the pores being closed and transformed into bubbles at the expense of compression settling. Below this level, a slow increase of the density and a decrease of porosity is caused only by compression settling. Thus, in the course of 4-5 years (depending on the conditions of a given year), each annual layer is subjected to "washing" by meltwater. Consequently, the chemical composition of the ice is averaged for a number of years. This may apply especially to soluble trace components.

There were $131 \mathrm{~g} \mathrm{~cm}^{-2}$ of snow deposited at the drilling site in the 1989-90 balance year. Towards autumn, of this quantity there remained on the surface a $160 \mathrm{~cm}$ thick layer of snow, whose water equivalent was equal to $65 \mathrm{~g} \mathrm{~cm}^{-2}$ (if we ignore meltwater that was refrozen). Half of the snow melted during summer, and meltwater infiltrated the snow and firn. The internal infiltration feeding decreases gradually with depth, reaching down to the 1985-86 layer. Using the procedures described in detail in Bazhev (1980), we calculated the values of other components of the water-ice balance (cf. Table 1).

\section{LIGHT-ABSORBING MATERIAL AND MAJOR IONS}

Core one was divided into 306 samples covering the depth range $0-16.3 \mathrm{~m}$. These samples were processed through soot photometer and ion chromatograph. Table 2 gives an overview of concentration levels for the different components. The high variability is indicated by the high standard deviations in comparison to the means. For the soluble components the medians are on the order of those for the cleanest cloudwater samples taken over sub-Arctic Scandinavia (Ogren and Rodhe, 1986). Rather few data are available for comparison with the only insoluble component (EC). Median values for ten event samples of precipitation taken on the sample glacier during 1992 gave $0.078 \mathrm{mg} \mathrm{l}^{-1}$. The results on Mount Elbrus fall within the range $0.02-0.6 \mathrm{mgl}^{-1}$ measured by Ogren and others (1984) in precipitation over Sweden. There the median for 12 rural stations was $0.1 \mathrm{mga}^{-1}$ in April-August 1981.

The depth variation of the measured chemical components is plotted in Figure 6. The distribution of peaks and minima shows some similarity between the five components. With the correlation matrix given in Table 3 this covariation 


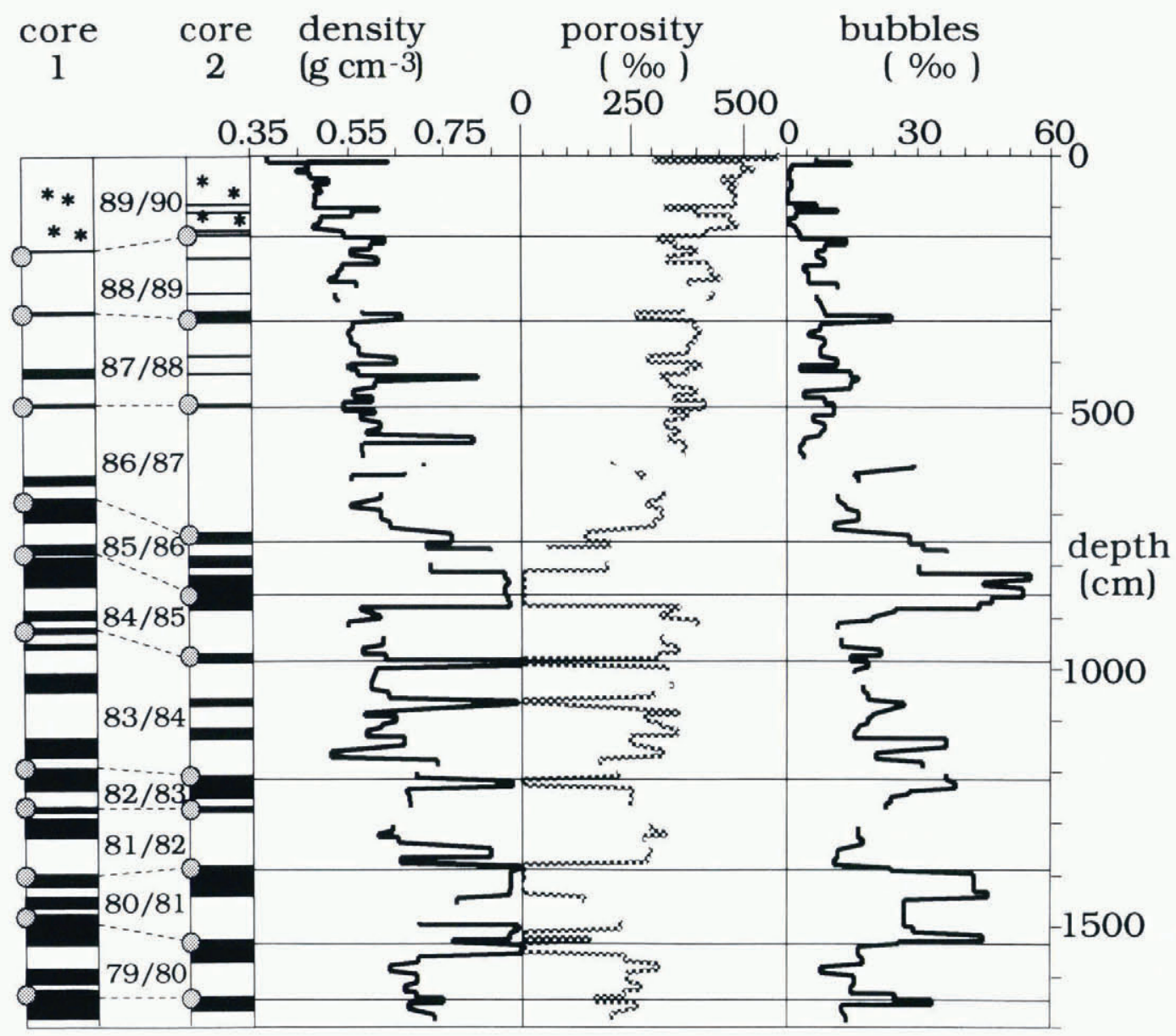

Fig. 4. Depth variation of density, porosity and bubble content of core two. Annual borders and visual features of cores one and two are given for comparison. Asterisks: snow; dark bands: ice; circles: horizons with visible mineral inclusions. The boundaries of annual layers in core two are given as thin horizontal lines.

total $\beta$ activity ${ }^{137} \mathrm{Cs}$ activity

$\left(\mathrm{Bq} \mathrm{ml}^{-1}\right) \quad\left(10^{-4} \mathrm{~Bq} \mathrm{ml}^{-1}\right)$

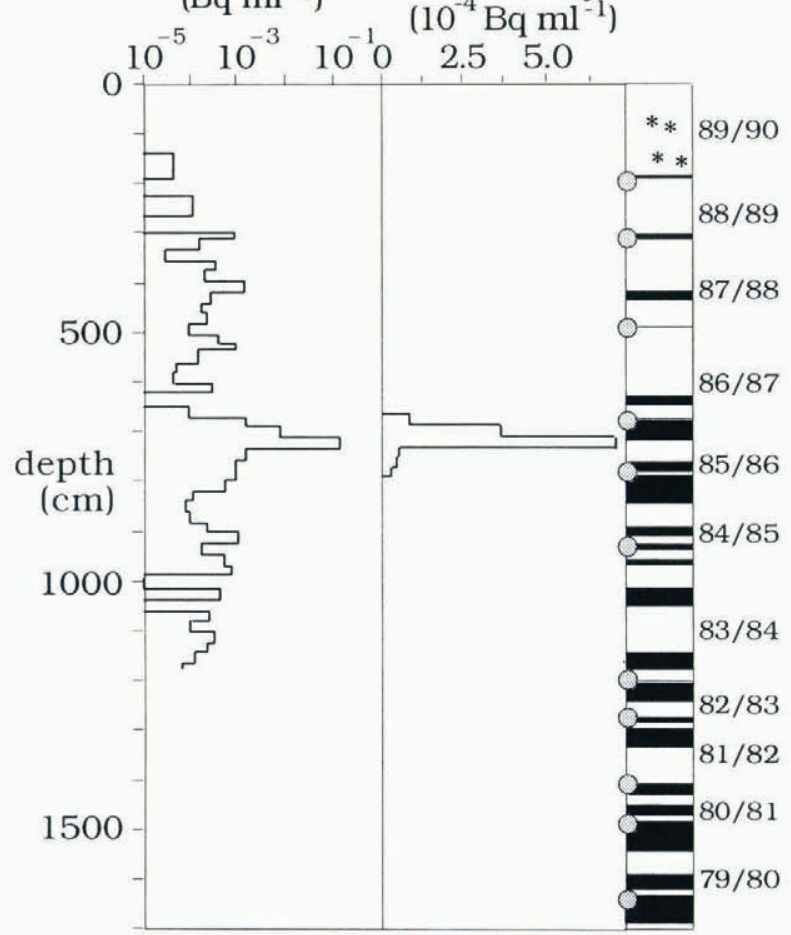

Fig. 5. Depth variation of total $\beta$ activity and ${ }^{137}$ Cs activity in core one. Outside the depth range covered by the histograms, the results were below the respective detection limits. Asterisks: snow; dark bands: ice; circles: horizons with visible mineral inclusions. can be quantified in order to discuss sources and processes of these trace substances. To a large extent, soot and sulphur are emitted from the same combustion sources. The primary sulphur emissions are mostly in the form of sulphur dioxide which is oxidised (mainly in the liquid phase of cloud water) to sulphate. In our results, light absorption and sulphate are not highly correlated. On the other hand, there is some correlation between sulphate and sodium, which can be interpreted as showing that both components come from a seasalt source of atmospheric aerosols. A hypothetical non-seasalt (nss) sulphate concentration can be calculated assuming average sea-water composition (35\%o salinity) for the source of hypothetical salt particles controlling the corresponding ions in the glacier samples. Nss-sulphate calculated in this way does not exhibit a higher correlation with the light absorption than the "uncorrected" sulphate data. This nss cal-

Table 1. Components of the water-ice balance in 198990 (core two)

Water-ice balance components

$\mathrm{g} \mathrm{cm}$

Total accumulation

Meltwater volume

Unmelted snow residue

Internal infiltration feeding

Meltwater runoff

Annual mass balance, including internal feeding

into firn layers 
Table 2. Average winter and summer concentrations of EC and major ions in different layers of the firn mass at $4100 \mathrm{~m}$ altitude (core one) compared to data on other glaciers

\begin{tabular}{|c|c|c|c|c|c|c|}
\hline $\begin{array}{l}\text { Part of the profile } \\
\text { depth }\end{array}$ & Horizons & $\begin{array}{c}E C \\
\mathrm{mgl}^{-1}\end{array}$ & $\begin{array}{l}\mathrm{SO}_{4}^{2} \\
\mu \mathrm{eq} \mathrm{I}^{-1}\end{array}$ & $\begin{array}{c}\mathrm{Na}^{+} \\
\mu \mathrm{eq} \mathrm{I}^{-1}\end{array}$ & $\begin{array}{c}K^{+} \\
\mu \mathrm{eq} \mathrm{l}^{-1}\end{array}$ & $\begin{array}{l}\mathrm{NO}_{3}^{-} \\
\mu \mathrm{eqI}{ }^{-1}\end{array}$ \\
\hline \multirow{3}{*}{$\begin{array}{l}\text { Upper part } \\
(0-670 \mathrm{~cm})\end{array}$} & Summer & 0.14 & 1.7 & 2.1 & 1.4 & 1.8 \\
\hline & Winter & 0.03 & 1.2 & 1.7 & 0.9 & 1.5 \\
\hline & Mean & 0.05 & 1.3 & 1.7 & 0.9 & 1.7 \\
\hline \multirow{3}{*}{$\begin{array}{l}\text { Middle part } \\
(670-1200 \mathrm{~cm})\end{array}$} & Summer & 0.14 & 5.1 & 17 & 2.1 & 2.7 \\
\hline & Winter & 0.05 & 1.6 & 3.8 & 1.1 & 2.8 \\
\hline & Mean & 0.06 & 2.0 & 5.6 & 1.2 & 2.9 \\
\hline \multirow{3}{*}{$\begin{array}{l}\text { Lower part } \\
(1200-1640 \mathrm{~cm})\end{array}$} & Summer & 0.11 & 0.8 & 3.6 & 2.0 & 1.4 \\
\hline & Winter & 0.02 & 0.5 & 1.8 & 0.6 & 1.3 \\
\hline & Mean & 0.04 & 0.5 & 2.5 & 1.0 & 1.3 \\
\hline \multirow[t]{3}{*}{ Total core } & Summer & 0.13 & 2.1 & 6.4 & 1.7 & 1.9 \\
\hline & Winter & 0.04 & 1.8 & 2.4 & 0.9 & 1.9 \\
\hline & Mean & 0.05 & 1.3 & 3.2 & 0.99 & 2.0 \\
\hline & $0.03^{2}$ & 6.2 & 0.9 & 0.4 & 4.5 \\
\hline \multirow{2}{*}{\multicolumn{2}{|c|}{$\begin{array}{l}\text { Amundsenisen/ } \\
\text { Kongsvegen, Svalbard } \\
\text { (Arkhipov and others, 1992) }\end{array}$}} & $0.02^{3}$ & 15 & 60 & 1.5 & 3.4 \\
\hline & & & 18 & 78 & 1.8 & 29 \\
\hline \multicolumn{2}{|c|}{$\begin{array}{l}\text { Central Greenland } \\
\text { (Delmas and Legrand, 1989) }\end{array}$} & $0.002^{4}$ & 1.3 & $0.5^{5}$ & $0.04^{5}$ & 1.1 \\
\hline
\end{tabular}

Average snow composition for winter and spring of the years 1991-93 at four sites of about $3500 \mathrm{~m}$ altitude and higher (Nickus and others, 1997).

${ }^{2}$ Average of nine samples taken at Colle Gnifetti, Swiss Alps ( $4450 \mathrm{~m}$ a.s.l.) (Lavanchy, 1995).

${ }^{3}$ Median value determined by the same method as in the present study in samples of superimposed ice covering the period 1954-79 on Storøya, Svalbard (Hansson and others, 1993).

${ }^{4}$ Average of two samples at Camp Century, Greenland (Chylek and others, 1987).

${ }^{5}$ Uncertain values, calculated from chlorine concentrations. culation can be seen as an upper limit of a possible nss correction since the salinities of the nearest seas are lower than that of average sea water (Black Sea $=19 \%$, Caspian Sea $=13 \%$, Sea of Azov $=12 \%$; Kosarev and Jablonskaya, 1995). Thus, we conclude from the lack of correlation improvement that the light absorption in the core is controlled by the local crustal components rather than by EC from combustion sources.

Figure 6 gives the impression that the EC data do not provide any reliable relationship with the dust content in the glacier. Sometimes the EC peaks coincide with the boundaries of the annual layers. In those cases, the high concentrations of mineral particles can be determined visually. However, this linkage is frequently absent. It is known that the summer increase in mineral inclusions in glaciers has a strong inter-annual variability. Nevertheless, our EC data in the core confirm most of the visually determined horizons.

During the formation of a snowpack, the ion concentrations in the different layers are constant. They are controlled by the composition of solid precipitation, by dry deposition of aerosols and soluble gases and by relocation and transformation processes in the snowpack. In the present case, meltwater movements through the firn-to-ice transition are probably the most important (and most complicated) of the controlling processes. Ions are leached out of more homogeneous winter firn horizons and accumulate in summer layers. Intermediate layers of infiltration ice are also formed in winter layers. In spring, meltwater freezes in cold snow masses at the boundaries between snow layers of different structure and density. The thickness of these intermediate layers increases with time because the heat content

\section{Concentrations}

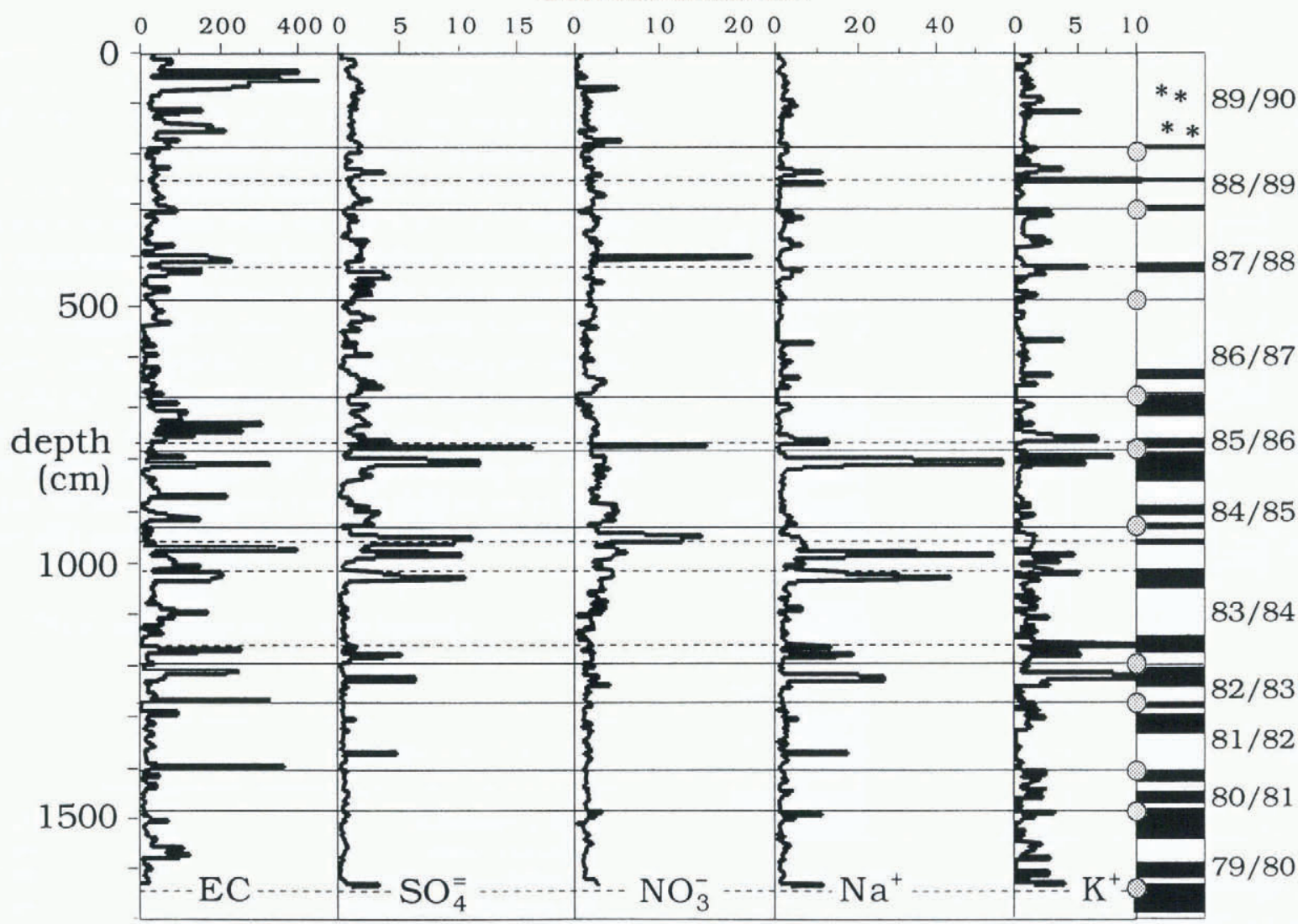

Fig. 6. Depth variation of EC and major ions in core one. EC in $\mu \mathrm{gl}^{-1}$, all ions in $\mu e q l^{-1}$. Asterisks: snow; dark bands: ice; circles: horizons with visible mineral inclusions. The boundaries of annual layers in core two are given as thin horizontal lines. Dotted line shows prominent ice layers in winter horizons. 
Table 3. Correlation matrix of the chemical results of core one

\begin{tabular}{llllll}
\hline Component & \multirow{2}{*}{$\mathrm{EC}$} & $\mathrm{SO}_{+}{ }^{2}$ & $\mathrm{Na}$ & $\mathrm{K}^{+}$ & $\mathrm{NO} \mathrm{S}^{-}$ \\
\hline $\mathrm{EC}$ & \multirow{2}{*}{1.00} & 0.12 & 0.19 & 0.10 & 0.06 \\
$\mathrm{SO}_{4}{ }^{+}$ & & 1.00 & 0.66 & 0.19 & 0.61 \\
$\mathrm{Na}^{+}$ & & & 1.00 & 0.43 & 0.21 \\
$\mathrm{~K}^{+}$ & & & & 1.00 & 0.04 \\
$\mathrm{NO}_{3}$ & & & & & 1.00 \\
\hline
\end{tabular}

of the ice is lower than that of firn and also because of the resistance to meltwater transport. On average, such layers in winter horizons have 1.5 times higher ion concentrations than summer layers.

Figure 6 shows an increase in ion concentrations in most water-blocking layers (as indicated by density and visual inspection). However, this increase depends on the mobility of the ions. $\mathrm{NO}_{3}$ seems to penetrate through the profile most easily. Its vertical distribution is most homogeneous. The number of peaks is lowest and summer peaks are no higher than winter peaks. The migration ability of $\mathrm{SO}_{4}{ }^{2-}$ is close to that of $\mathrm{NO}_{3}{ }^{-}$by all these characteristics. The similarity is borne out by the relatively high correlation of the two ions (cf. Table 3).

Of all the ions, $\mathrm{Na}^{+}$is characterised by the sharpest depth fluctuations and strongest peaks. On average, sodium concentrations in summer horizons are 2.6 times higher than in winter layers. Most peaks coincide with those of $\mathrm{K}^{+}$. Their migration is stopped by any horizons and by structural inhomogeneities in the profile. Thus, the ions form a sequence in their migration ability. $\mathrm{NO}_{3}>\mathrm{SO}_{4}{ }^{2}$ $>\mathrm{Na}^{+}>\mathrm{K}^{+}$, which is in agreement with observations at other locations.

The variability in chemical profiles allows the division of the total core into three parts. The upper part $(0-6.7 \mathrm{~m})$ comprises the four annual layers $1986-87$ to 1989-90. Its density increases with depth, with an average value of $0.58 \mathrm{~g} \mathrm{~cm}^{-3}$. The number of ice layers in this part is relatively small, and ion concentrations usually increase in dense lenses of ice in "winter" horizons. Summer horizons are more easily penetrated by meltwater. Except for $\mathrm{K}^{+}$, ion migration is easy.

The middle part of the core $(6.7-12 \mathrm{~m})$ is characterised by the highest concentrations of all ions and the strongest ion peaks in ice layers (cf. Table 2). Here the concentration of summer horizons is $3-4$ times higher that in winter layers, and in some samples peak increases of 20-40 times occur.
This part of the core comprises three annual layers and its structure is largely controlled by the conditions in summer 1986. The snow residue of this year is small because of the exceptionally high snowmelt. However, the meltwater accumulated and froze in this core section and in two lower layers. A number of ice layers were formed in this process. In the most pronounced layers peaks of most ions coincided.

The bottom part of the core is characterised by low ion concentrations and small fluctuations. This finding is the result of comparatively small snowmelt in 1982-84 and also of the "protective" layers against infiltration from above by massive horizons in the middle part of the core. In general, the bottom half of the total profile corresponds to colder conditions of ice formation, whereas the upper part is controlled by conditions that are close to the lower border of the zone of cold infiltration and recrystallisation.

In Table 2 our results are compared to those from other Northern Hemisphere results in Europe and the Arctic. One would expect the closest similarity to be with the high alpine sites. However, sulphate and nitrate levels are considerably higher in central Europe than on Mount Elbrus. This is understandable considering the proximity of the alpine sites to the large European combustion sources. The much higher sulphate and sodium levels in the Svalbard samples can both be explained by the low-level marine location of the site. In winter, sulphate material is imported as Arctic haze from Eurasia, while in summer there are strong biogenic sulphate sources in the Svalbard region (Heintzenberg and Leck, 1994). In the lowest part of Mount Elbrus, winter core levels approach sulphate, sodium and nitrate levels as measured in central Greenland, while EC levels are still an order of magnitude higher. We attribute the difference in EC concentrations to a significant crustal component in our EC signal on Mount Elbrus, even in winter.

\section{METALS IN DUST DEPOSITS AND RIVER RUNOFF}

Samples were taken from the melting surface of the Garabashi glacier at the end of summer 1993 in the altitude range $3830-4160 \mathrm{~m}$ (cf. the sampling points in Figure 1). At this altitude the crustal contribution of metals from surrounding ice-free slopes of the mountain is negligible. Rather, the concentration of heavy metals in the fine dust of the glacier deposits is considerably higher than values obtained during the study of Quaternary deposits in the alpine zone of the Caucasus ridge (cf. Table 4). In particular, this holds for the

Table 4. Heavy metal content of fine particulate matter on glacier surfaces and in the meltwater rivers $\left(n \times 10^{-3} \% \%_{m}\right)$ in 1993 (cf. Fig. I for location of sampling points, except "Azau Hotel")

\begin{tabular}{|c|c|c|c|c|c|c|c|c|c|c|}
\hline Sampling points & $z_{n}$ & $P b$ & Sr & Co & $M i$ & $\mathrm{Cr}$ & $M n$ & As & $R b$ & $z^{\prime}$ \\
\hline Garabashi glacier, meteo site $(3830 \mathrm{~m})$ & 14 & 7.3 & 35 & 6.6 & 5.1 & 11 & 58 & 2.0 & 11 & 28 \\
\hline Garabashi glacier, east of path ( $3835 \mathrm{~m})$ & 16 & 7.8 & 35 & 4.8 & 5.1 & 12 & 58 & 1.9 & 11 & 29 \\
\hline Garabashi glacier stake 11 (3930 m) & 22 & 11 & 30 & 7.6 & 7.1 & 13 & 77 & 3.1 & 12 & 28 \\
\hline Garabashi glacier stake $3(4160 \mathrm{~m})$ & 18 & 8.3 & 31 & 21 & 5.1 & 9.4 & 88 & 1.7 & 12 & 24 \\
\hline $\begin{array}{l}\text { Garabashi river, exit from gorge, upstream } \\
\text { of "Azau Hotel" ( } 2380 \mathrm{~m})\end{array}$ & 6.5 & 1.7 & 45 & 0.9 & 0.9 & 7.1 & 59 & 2.1 & 12 & 33 \\
\hline $\begin{array}{l}\text { Bolshoy Azau river, upstream of Maliy Azau } \\
\text { waterfall }(2350 \mathrm{~m})\end{array}$ & 5.8 & 3.3 & 31 & 1.6 & 1.3 & 1.7 & 56 & 1.5 & 16 & 28 \\
\hline $\begin{array}{l}\text { Quaternary deposits in alpine zone of } \\
\text { Caucasus area (Dobrovolskiy and } \\
\text { Ryakinskaya, 1967) }\end{array}$ & 8 & - & 30 & 1 & 3 & 1 & 25 & - & & 10 \\
\hline
\end{tabular}


relative content (per unit of solid matter) of elements like $\mathrm{Zn}, \mathrm{Pb}, \mathrm{Cr}$, Co and $\mathrm{Ni}$, which are higher than in suspended solid particles in the rivers flowing out of the glacier proper (cf. Table 4). During summer melting, the runoff from the glacier tongue is 3-4 times higher than the runoff from the firn area, in which case a $3-4 \mathrm{~m}$ thick layer of old ice, formed 100-200 years ago, when anthropogenic pollution was much less severe, melts away. This clean water dilutes the trace substances in the river flowing out of the glacier. Thus, the glacier ice acts as an "accumulator", trapping anthropogenic pollutants. Should our preliminary results of metal analyses be confirmed in the future, the glaciers at present may be regarded as cleaning river waters and thus the connected ecosystems as a whole. In decades to come, however, as a result of ice movement in the glaciers, the ice layers that have accumulated these elements will begin to melt away on glacier tongues.

\section{CONCLUSIONS}

With two short ice cores taken at $4100 \mathrm{~m}$ elevation on the Bolshoy Azau glacier and samples of snow and ice taken at the surface of the Garabashi glacier on the southern slope of Mount Elbrus, the possibilities were explored of using the ice to study trace substances deposited after long-range transport from Europe. The sampling site is well characterised from a glaciological point of view. Visual inspection of the cores, confirmed by a radioactivity horizon from the Chernobyl accident, established a time-scale covering 11 complete layers. The radioactivity data also proved the remote origin of the deposited trace substances. The soluble and insoluble impurities in the core (major ions and lightabsorbing material) had values which were comparable to cloud-water and snowpack composition at remote continental and Arctic sites, thus indicating the usefulness of Mount Elbrus as an archive for atmospheric composition downwind of Europe.

\section{REFERENCES}

Arkhipov, S. M., M.Yu. Moskalevskiy, A. F. Glazovskiy, P. Maevskiy and S. Witlow. 1992. Geokhimiya neprotayavshego snezhnogo pokrova lednika Konsvegen i lednikovogo plato Amundsena na Shpitsbergena [Geochemistry of unmelted snow cover of the Kongsvegen Glacier and the Amundsen Ice Plateau in Spitsbergen]. Mater. Glyatsiol. Issled. 75, 22-35.

Bazhev, A. B. 1980. Metody opredeleniya vnutrennego infil'tratsionnogo pitaniya lednikov [Methods of determining internal seepage alimentation of glaciers]. Mater. Glyatsiol. Issled. 39, 73-81 (Russian); 147-154 (English)

Bazhev, A. B. and V.Ya. Bazheva. 1962. [Novaya Zemlya: ice structure.] Moscow, Akademiya Nauk SSSR. Institut Geografiy.

Benkovitz, C. M., C. M. Berkowitz, R. C. Easter, S. Nemesure, R. Wagener and S. E. Schwartz. 1994. Sulfate over the North Atlantic and adjacent continental regions: evaluation for October and November 1986 using a three-dimensional model driven by observation-derived meteorology. f. Geophys. Res., 99 (D10), 20,725-20,756.

Borovik, E. S. and V. I. Kravtsova. 1970. 5. Basseyny rek Malki, Baksana 15. Basins of the rivers Malki and Baksan]. Leningrad, Gidrometeoizdat. (Katalog lednikov SSSR [Catalogue of glaciers of the USSR], Vol. 8.)

Chylek, P. and 7 others. 1987. Aerosol and graphitic carbon content of snow. F. Geophys. Res., 92(D8), 9801-9809.

Csongor, E., A. Z. Kiss, B. M. Nyakó and E. Somarjai. 1986. Chernobyl fallout in Debrecen, Hungary. Nature, 324 (6094), 216.

Delmas, R. J. and M. Legrand. 1989. Long-term changes in the concentrations of major chemical compounds (soluble and insoluble) along deep ice cores. In Oeschger, H. and C. C. Langway, Jr, eds. The environmental record in glaciers and ice sheets. Chichester, etc., JohnWiley and Sons, 319-341.

Delmas, R. and M. Pourchet. 1977. Utilisation de filtres échangeurs d'ions pour l'étude de l'activité $\beta$ globale d'un carottage glaciologique. International Association of Hydrological Sciences Publication 118 (Symposium at Grenoble 1975 - Isotopes and Impurities in Snow and Ice), 159-163.

Dobrovolskiy, V.V. and M.V. Ryakinskaya. 1967. Landscape-geochemical zones of the northern slope of Great Caucasus. In Geochemistry of landscape, $125-140$.

Hansson, M., H. -C. Hansson, S. Johnsen and J. Heintzenberg. 1993. Chemical composition of insoluble particles in superimposed ice on Storeya, Svalbard. Stockholm, University of Stockholm. Department of Meteorology. (Report CM-82.)

Heintzenberg, J. 1982. Size-segregated measurements of particulate elemental carbon and aerosol light absorption at remote Arctic locations. Atmos. Environ., 16, 2461-2469.

Heintzenberg, J. 1988. A processor-controlled multisample soot photometer. Aerosol Sci. Tech., 8, 227-233.

Heintzenberg, J. and C. Leck. 1994. Seasonal variation of the atmospheric aerosol near the top of the marine boundary layer over Spitsbergen related to the Arctic sulphur cycle. Tellus, 46B, $52-67$.

Kosarev, A. N. and E. A. Jablonskaya. 1994. The Caspian Sea. The Hague, SPB Academic Publishing.

Kotlyakov, V. M. and M.Ya. Plam. 1964. Osobennosti akkumulyatsii i kosvennyye sposoby podscheta tverdykh osadkov na lednike [Peculiarities of accumulation and indirect methods of computing solid precipitation on the glacier]. Mater. Glyatsiol. Issled. 10, 57-66.

Lavanchy, V. M. H. 1995. Russmessungen in Schneeproben. (M.Sc. thesis, Institute for Analytical, Physical and Inorganic chemistry, Bern University.)

Matyukhin, G. D. 1960. [Climate data on altitudinal belts of the Elbrus southern slope]. In [Collected information on MSU research under the IGI program 7. Moscow, Akademii Nauk SSSR. Institute of Geography, 130-194. (Report 5.M: Data of Glaciological Studies.)

Nickus, U. and 19 others. 1997. SNOSP: ion deposition and concentration in high alpine snow packs. Tellus, 49B, 56-71.

Nijampurkar, V. N. and D. K. Rao. 1990. Evidence of Chernobyl fallout on a temperate Himalayan glacier. Current Sci., 59(23), 1239- 1241.

Ogren, J. and H. Rodhe. 1986. Measurements of the chemical composition of cloudwater at a clean air site in central Scandinavia. Tellus, 38B, 190-196.

Ogren, J., P.J. Groblicki and R. J. Charlson. 1984. Measurement of the removal rate of elemental carbon from the atmosphere. Sci. Total Environ., 36,329338 .

Pinglot, J. F. 1978. Dispositif automatique de mesure de la radioactivité $\beta$ à bas niveau déchantillons de neige. Grenoble, Centre National de la Recherche Scientifique. Laboratoire de Glaciologie.

Pinglot, J. F. and M. Pourchet. 1979. Low-level beta counting with an automatic sample changer. Nucl. Instrum. Methods, 166 (3), 483-490.

Pinglot, J. F. and M. Pourchet. 1994. Spectrométrie gamma à très bas niveau avec anti-Compton $\mathrm{NaI}(\mathrm{Tl})$, pour l'étude des glaciers et des sédiments. CEA (Commissariat à l'Énergie Atomique) Note 2756, 291- 296.

Pinglot, J. F. and M. Pourchet. 1995. Radioactivity measurements applied to glaciers and lake sediments. Sci. Total Environ., 173-174, 211-223. 